Original Research

\title{
Using Sodium Trithiocarbonate to Precipitate Heavy Metals from Industrial Wastewater - from the Laboratory to Industrial Scale
}

\author{
Maciej Thomas $^{1}$, Dariusz Zdebik ${ }^{2 *}$, Barbara Bialecka ${ }^{3}$ \\ ${ }^{1}$ Chemiqua Company, Kraków, Poland \\ ${ }^{2}$ Central Mining Institute, Department of Water Protection, Katowice, Poland \\ ${ }^{3}$ Central Mining Institute, Department of Environmental Monitoring, Katowice, Poland
}

Received: 22 June 2017

Accepted: 15 August 2017

\begin{abstract}
This paper presents the possibility of using sodium trithiocarbonate to remove heavy metals such as copper, nickel, and tin from industrial wastewater generated by the production of printed circuit boards (PCBs). Initial metal removal studies aimed at selecting an effective precipitant and optimizing the precipitation process were conducted on an laboratory scale. The smallest concentrations of copper, nickel, and tin in treated wastewater $(\mathrm{Cu} 0.09 \mathrm{mg} / \mathrm{L}, \mathrm{Ni} 0.009 \mathrm{mg} / \mathrm{L}, \mathrm{Sn}<0.005 \mathrm{mg} / \mathrm{L})$ were obtained after using a stoichiometric sodium trithiocarbonate dose at $\mathrm{pH}$ 9.0-9.5. Optimizing the metal removal process was possible by using the surface response method to obtain a good adjustment of the experimental data to the data obtained from the model $\left(\mathrm{R}^{2}=0.9307, \mathrm{R}_{a d i}^{2}=0.8845\right)$. The results of laboratory and model studies were used during industrial-scale testing in a wastewater treatment plant located in a PCB manufacturing plant. Optimization the wastewater treatment process on an industrial scale allowed us to obtain treated wastewater with very low copper $(<0.005-0.014 \mathrm{mg} / \mathrm{L})$, nickel $(<0.005-0.008 \mathrm{mg} / \mathrm{L})$, and tin $(<0.005 \mathrm{mg} / \mathrm{L})$ concentrations.
\end{abstract}

Keywords: heavy metals, copper, nickel, tin, wastewater, sodium trithiocarbonate, complexing agents, industrial wastewater

\section{Introduction}

The intensive development of industry is related to the increasing degree of pollution of the natural environment by emitting organic and inorganic pollutants into the air, water, and soil. Among inorganic substances, chemicals containing heavy metals are particularly dangerous because they are not biodegradable and can accumulate

*e-mail: dzdebik@gig.eu in living organism's causing many adverse changes. It is assumed that heavy metals are elements with atomic mass between 63.5 and $200.6 \mathrm{u}$ and density greater than $5 \mathrm{~g} / \mathrm{L}$ [1]. Adoption of the above criteria causes the inclusion of such elements as copper, nickel, and tin. Copper ions (II) are on the one hand a vital microelement essential for the functioning of living organisms, but on the other hand, even at low concentrations they cause a reduction of vital functions of the organisms responsible for the biodegrading organic pollutants in wastewater treatment processes such as: denitrifying bacteria, heterotrophic 
bacteria-decomposing glucose, and nitrifying bacteria [2]. High copper concentrations were recorded in water from copper mines $(1,550 \mathrm{mg} / \mathrm{L})$ and in wastewater originating from the production of semiconductors $(5-100 \mathrm{mg} / \mathrm{L})$ [34]. Also, in wastewater from the production of PCBs, the presence of copper (II) ions in the range of $0.1-60 \mathrm{mg} / \mathrm{L}$ was noted, depending on the type of process from which the wastewater originated. The highest concentration of copper was found in wastewater from acid and ammonia etching and the brushing process [5].

Nickel is an element commonly used in industry and it is therefore also a constituent of water systems where it is present, similarly to nickel, in the form of many chemical compounds. Nickel (II) ions also have toxic effects on many aquatic organisms, including freshwater fish such as: rainbow trout (Oncorhynchus mykiss), three-spined stickleback (Gasterosteus aculeatus), roach (Rutilus rutilus), perch (Perca fluviatilis), and dace (Leuciscus leuciscus). A lethal concentration of nickel (II) ions ( $\mathrm{LC}_{50}, 96$ hours) for the above-mentioned species was 19.3-61.2 mg/L [6]. Nickel (II) ions may have a toxic impact on aquatic organisms, possibly by the disturbance of $\mathrm{Ca}^{2+}$ homeostasis, $\mathrm{Mg}^{2+}$ homeostasis, $\mathrm{Fe}^{2+} / \mathrm{Fe}^{3+}$ system homeostasis, oxidative damage caused by reactive oxygen forms, and allergic response of respiratory epithelium [7]. Nickel concentrations in industrial wastewater vary, but in the case of this element, that wastewater is highly toxic and possibly carcinogenic. In addition, only $30-40 \%$ of all metals used in galvanic processes are effectively used and placed as galvanic coatings.

The remaining amount (60-70\%) pollutes rinse water, which may contain toxic metals in concentrations even up to $1,000 \mathrm{mg} / \mathrm{L}$ [8]. Non-organic tin (II) and tin (IV) compounds, as opposed to copper (II) and nickel (II) compounds, are characterized by low toxicity in relation to aquatic and terrestrial organisms, mainly due to their low solubility, poor absorption, frequently low accumulation in tissue, and rapid excretion [9]. Despite its low toxicity compared to other metals, tin compounds must also be removed from industrial wastewater to protect the natural environment from excessive pollution, as required by law. Removal of heavy metals from wastewater can be accomplished by the use of unit processes such as: chemical precipitation, coagulation, flocculation, complexing, adsorption on activated carbon, ion exchange, solvent extraction, foam flotation, cementation, and others. Chemical precipitation processes are one of the most common methods used in industry for the removal of heavy metals from nonorganic wastewater due to the speed of the process and its simplicity [10]. Heavy metal precipitation processes take place as a result of wastewater alkalisation with $\mathrm{Ca}(\mathrm{OH})_{2}$ slurry or $\mathrm{NaOH}$ solution to a certain $\mathrm{pH}$ value required to precipitate metal ions present in wastewater in the form of hydroxides. Typically, $\mathrm{pH} 8-11$ is used, where the solubility of most metal hydroxides is the lowest. Metal hydroxide precipitated in the form of sediment can be removed by flocculation, sedimentation, and filtration. The method of metals precipitation by wastewater alkalisation is easy to use, but it tends to be ineffective as far as precipitation of amphoteric hydroxides is concerned, and the presence of complexing agents in wastewater, which prevent quantitative precipitation of metal ions [11]. These problems can be eliminated by the use of metal sulphides in a soluble $\left(\mathrm{Na}_{2} \mathrm{~S}, \mathrm{NaHS}\right)$ or insoluble $(\mathrm{FeS})$ form for precipitation, which at acid $\mathrm{pH}(\mathrm{pH}<3)$ release $\mathrm{H}_{2} \mathrm{~S}$ and allow precipitation of heavy metal ions in the form of sulphides.

It is known that the solubility product of metal sulphides is much lower than the solubility product of metal hydroxides, and therefore the use of sulphides enables us to obtain treated wastewater with a lower content of heavy metals than in the case of metal hydroxide precipitation. The method with the use of sulphides is effective for wastewater containing metal $(\mathrm{Cr}$, $\mathrm{Ni}, \mathrm{Zn}$ ) mixtures as well as in the presence of complexing compounds $\left(\mathrm{CN}^{-}\right)$, but its use is associated with the formation of large amounts of sludge and requires the use of more reagents. Despite these inconveniences, it is still used due to its high efficiency and low installation costs [12]. When using this method, there is a risk of $\mathrm{H}_{2} \mathrm{~S}$ gas release, as precipitation of metals is carried out in acidic environments. This risk can be eliminated by using other sulphur-containing compounds for precipitation, such as: dimethyl-, diethyl-, diphenyl-dithiocarbamic sodium salt, its derivatives [13-14], or trimercaptotriazine sodium salt [15-17] in an inert or alkaline medium. The purpose of the present study was to determine the efficacy of sodium trithiocarbonate $\left(\mathrm{Na}_{2} \mathrm{CS}_{3}\right)$ as a precipitation reagent of $\mathrm{Cu}$ (II), Ni (II), and Sn (II) ions from industrial wastewater from PCB production and containing complexing compounds. The research was conducted on a laboratory and industrial scale.

The testing in the laboratory in the first stage involved the selection of the most effective precipitant and in the second stage, the optimization of metal removal using the RSM method. The obtained results of model tests carried out on a laboratory scale were used to optimize the heavy metals precipitation process on the industrial scale, at the wastewater treatment plant located in the production of PCBs.

\section{Material and Methods}

\section{Material and Chemical Reagents}

Laboratory-scale research was carried out on a sample of actual wastewater collected in a wastewater treatment plant of a PCB plant located in Poland. Samples of raw wastewater were collected for five consecutive days, after which their composition was averaged by mixing. The collected wastewater samples and the averaged test sample were not fixed and their physico-chemical composition is shown in Table 1. The following precipitants were used: $\mathrm{Na}_{2} \mathrm{~S} \cdot 9 \mathrm{H}_{2} \mathrm{O}$ (analytical grade, POCH, Poland), Furosep CW3 (40\% solution of sodium dimethyldithiocarbamate, Chemische Fabrik Wocklum GmbH \& Co. KG, 
Germany), TMT 15 (15\% solution of sodium trimercaptos-triazine, Donauchem, Poland), and $44.26 \%$ and $10.00 \%$ solution of $\mathrm{Na}_{2} \mathrm{CS}_{3}$ (sodium trithiocarbonate, KiZChS Siarkopol S.A., Poland). Moreover, we used the following reagents: $\mathrm{Ca}(\mathrm{OH})_{2}$ (Chempur, Poland), $\mathrm{NaOH}$ (POCH, Poland), $\mathrm{HCl}$ (POCH, Poland), Praestol 2500 (Ashland Deutschland $\mathrm{GmbH}$, Germany) and $\mathrm{FeCl}_{3} \cdot 6 \mathrm{H}_{2} \mathrm{O}$ (Chempur, Poland). All reagents had analytical purity and $30 \% \mathrm{NaOH}$ (technical grade), $36 \% \mathrm{HCl}$ (technical grade), $\mathrm{FeCl} 3$ (Donau Klar Smart, Donauchem, Poland), and anion flocculant (Furoflock CW277, Chemische Fabrik Wocklum GmbH \& Co. KG, Germany) were used at the stage of industrial testing.

\section{Analytical Methods}

The reaction was determined using the WTWinolab $\mathrm{pH} / \mathrm{IONCond} 750$ device using the combination electrode SenTix81according to PN-EN ISO 10523:2012, specific electrical conductivity using the TetraCon325 electrode according to EN 27888:1999 and the redox potential was determined using the Elmetron CPC411 with the platinum electrode ErPt-11 (Hydromet, Poland). Turbidity was determined by nephelometric method using a Cyberscan IR Turbidimeter TB1000 according to PN-ISO 7027:2003 and colour using a SPEKOL 1200 Spectrophotometer according to PN-ISO 7887:2012. Chemical oxygen demand (COD) was determined by spectrophotometric method using sealed tubes and a Spekol 1200 spectrometer according to PN-ISO 15705:2005, and total organic carbon (TOC) by high-temperature combustion at $680^{\circ} \mathrm{C}$ with IR detection using a Shimadzu TOC$\mathrm{L}_{\mathrm{CPH}}$ analyzer according to PN-EN 1484:1999. Chlorides were determined by titrimetric method according to PNISO 9297:1994 and sulphates (VI) by weight method according to PN-ISO 9280:2002. Heavy metals $(\mathrm{Cu}, \mathrm{Ni}$, $\mathrm{Sn})$ were determined by the ISP-OES method using an Optima 5300DV spectrometer (Perkin Elmer) according to PN-EN ISO 11885:2009. Complexing compounds were determined by spectrophotometry using a Nanocolor Organische Komplexbildner 10 (Bi(III)/xylenol orange, Macherey-Nagel GmbH, Germany), according to DIN 38409-H26, using the following bismuth complex index calculation $\left(\mathrm{I}_{\mathrm{BiK}}\right): 1 \mathrm{mg} / \mathrm{L} \mathrm{I}_{\mathrm{BiK}}=1.61 \mathrm{mg} / \mathrm{L} \mathrm{Na} \mathrm{NDT}_{2}$. Finally, sulphides were determined by spectrophotometric method, using Visocolor Sulfides 0.1-0.8 mg/L (sulphides/ N,N-dimethyl-1.4-phenylenediamine/Fe (III) sulphides, Macherey-Nagel GmbH, Germany).

\section{Methodology of Research}

Comparative studies of precipitation efficiency of copper (II), nickel (II), and tin (II) ions from wastewater were conducted using $\mathrm{Na}_{2} \mathrm{~S}$, Furosep CW3, TMT 15, and $44.26 \%$ solution of $\mathrm{Na}_{2} \mathrm{CS}_{3}$. Precipitation of metals in the case of using Furosep CW3 and TMT 15 was carried out strictly according to the instructions in the specification sheets of these products, using $1 \mathrm{~L}$ wastewater samples. Precipitation using $\mathrm{Na}_{2} \mathrm{~S}$ was carried out at $\mathrm{pH} 6.5$ (the highest theoretical efficiency of copper precipitation in the form of sulphide), using a stoichiometric amount of $\mathrm{Na}_{2} \mathrm{~S} \cdot 9 \mathrm{H}_{2} \mathrm{O}$. After $10 \mathrm{~min}$, the $\mathrm{pH}$ was adjusted to 7.5 , and $2 \mathrm{~mL}$ of $0.05 \%$ Furoflock CW277 was added and then poured into a measuring cylinder of $1 \mathrm{~L}$ capacity and subjected to $30 \mathrm{~min}$. sedimentation. Likewise, precipitation was performed using Furosep CW3 by adding the stoichiometric amount of Furosep CW3 after adjustment of $\mathrm{pH}$ to 7.5. Precipitation using TMT 15 was carried out in two stages according to the manufacturer's guidelines for wastewater containing $\mathrm{Cu}^{2+}$ and $\mathrm{Ni}^{2+}$ ions.

In the first step, $\mathrm{Ca}(\mathrm{OH})_{2}$ was dosed to $\mathrm{pH} 7.0$, then $50 \%$ of $\mathrm{NaOH}$ to $\mathrm{pH} 9.0$ to precipitate free metals in the form of hydroxides. Then $1 \mathrm{~mL}$ of $0.05 \%$ Praestol 2500 was added and subjected to $30 \mathrm{~min}$. sedimentation. $\mathrm{V}_{\text {of sludge }}$ was measured at this stage and concentrations of $\mathrm{Cu}, \mathrm{Ni}$, and $\mathrm{Sn}$ were measured in pre-treated wastewater, which after sedimentation was decanted and purification was continued by adding a stoichiometric amount of TMT 15 in relation to the amount of metals remaining in the wastewater. After $30 \mathrm{~min}$. of reaction, $1 \mathrm{~mL}$ of $\mathrm{FeCl}_{3}$ $(10 \mathrm{~g} \mathrm{Fe} / \mathrm{L})$ solution and $0.2 \mathrm{~mL} 0.05 \%$ of Praestol 2500 was added and subjected to sedimentation for $60 \mathrm{~min}$. Precipitation using $\mathrm{Na}_{2} \mathrm{CS}_{3}$ was carried out by adding $1 \mathrm{~mL}$ $40 \%$ of $\mathrm{FeCl} 3$ to the sample of $1 \mathrm{~L}$ wastewater, correcting the $\mathrm{pH}$ to $9.0(30 \% \mathrm{NaOH})$ and adding a stoichiometric amount of $44.26 \% \mathrm{Na}_{2} \mathrm{CS}_{3}$ solution. After adjusting the $\mathrm{pH}$ to $9.0-9.5,2 \mathrm{~mL}$ of $0.05 \%$ Furoflock CW277 was added and subjected to $30 \mathrm{~min}$. sedimentation. After completion of the described precipitation processes, a sample of supernatant fluid was collected in each case (after 30 or 60 minutes of sedimentation, according to the recommended procedure) to determine the $\mathrm{pH}$ and $\mathrm{Cu}, \mathrm{Sn}, \mathrm{Ni}$, and $\mathrm{S}^{2-}$ concentrations. $\mathrm{V}_{\text {of sludge }}$ was measured after $30 \mathrm{~min}$. of sedimentation or in the case of TMT 15 precipitation after $60 \mathrm{~min}$. of sedimentation. Based on the analysis of $\mathrm{Cu}^{2+}, \mathrm{Ni}^{2+}$, and $\mathrm{Sn}^{2+}$ precipitation results performed on a laboratory scale, a mathematical model was developed to remove metals from the treated wastewater using the RSM method. The results of the model tests were used during continuous industrial tests in a wastewater treatment plant located in a PCB plant and shown schematically in Fig. 1.

The process of wastewater treatment in the wastewater treatment plant of $350 \mathrm{~L} / \mathrm{h}$ capacity, shown in Fig. 1, was as follows: (i) the averaged wastewater was pumped into the first chamber of the flow reactor where $\mathrm{pH}$ was measured and at $\mathrm{pH}$ greater than 5.5 the $\mathrm{HCl}$ was dosed with simultaneously dispensed coagulant (Donau Klar Smart) in the amount of $1 \mathrm{~L} / 1,000 \mathrm{~L}$ of wastewater, (ii) in the second chamber the wastewater was alkalised to $\mathrm{pH}$ ca. 9 with $30 \% \mathrm{NaOH}$ to precipitate metal hydroxides, (iii) in the third chamber $44.26 \%$ of $\mathrm{Na}_{2} \mathrm{CS}_{3}$ at a constant dose of $0.3 \mathrm{~L} / 1,000 \mathrm{~L}$ of wastewater was dosed to precipitate the complexed heavy metals, and (iv) in the fourth chamber, $0.05 \%$ of Furoflock CW277 solution was dosed in the amount of $2 \mathrm{~L} / 1,000 \mathrm{~L}$ of wastewater. Subsequently, the wastewater together with the precipitated sediments flowed through 


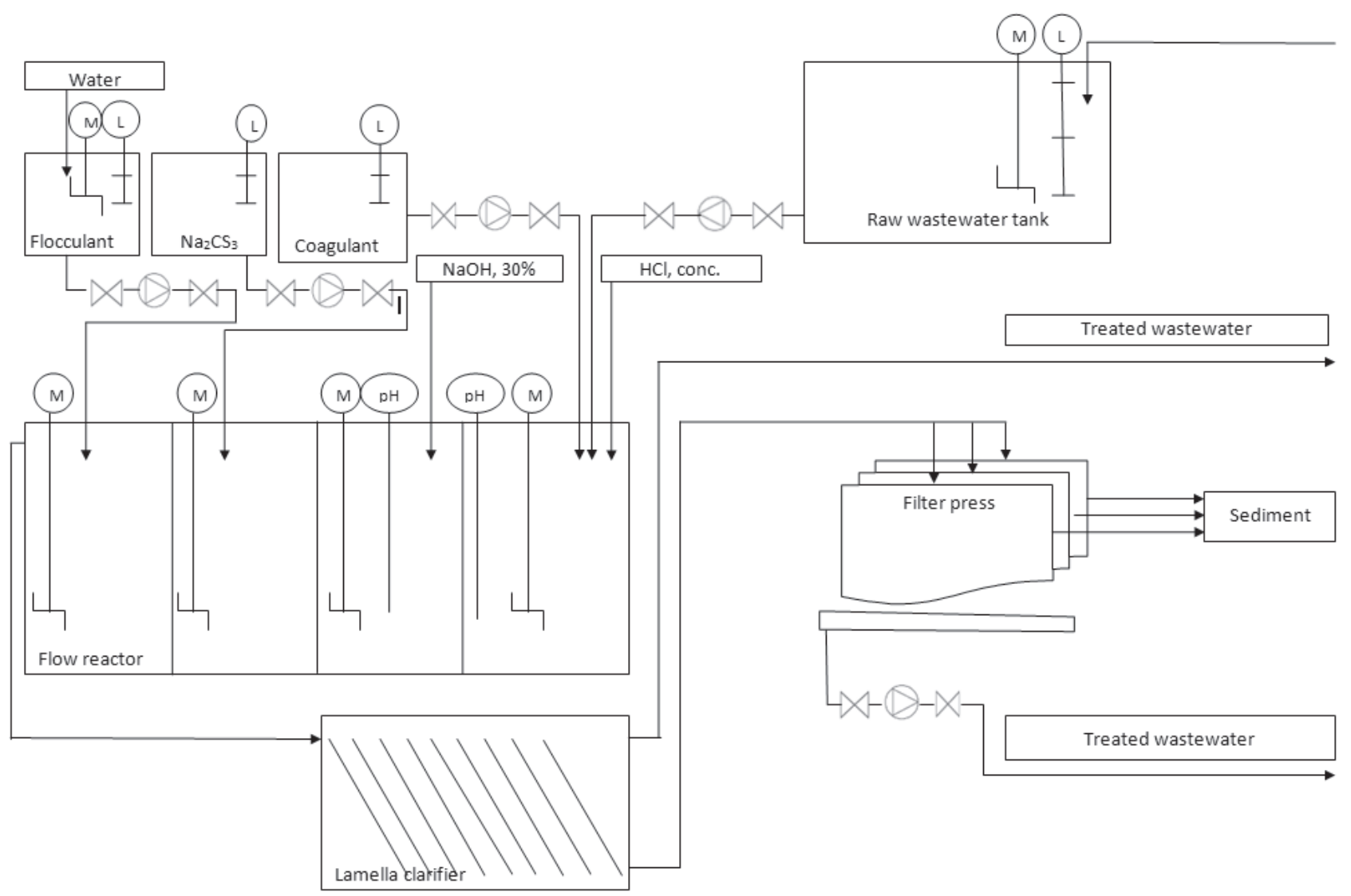

Fig. 1. Schematic diagram of the wastewater treatment plant (L-level sensor, M-stirrer, $\mathrm{pH}-\mathrm{pH}$ electrode).

the lamellar settler, where sedimentation of sediment took place, which was then directed by means of a spiral pump to the chamber press, while the treated wastewater was discharged into the well of treated wastewater.

Each of the flow reactor chambers was equipped with either fast- or low-speed agitators, and the first and second chamber additionally in the $\mathrm{pH}$ electrodes. The amount of dosed $30 \%$ of $\mathrm{NaOH}$ (final $\mathrm{pH}$ in the second chamber) was adjusted in such a way that after dosing $44.26 \%$ of $\mathrm{Na}_{2} \mathrm{CS}_{3}$, the final $\mathrm{pH}$ of the wastewater was about 9-9.5 and nearly complete precipitation of the metals occurred. Once the correct dosage was accomplished, for six consecutive days during normal plant operation, a sample of raw wastewater was pumped to the flow reactor and treated wastewater flowing from the well of treated wastewater to the municipal sewer system in order to determine $\mathrm{pH}$, turbidity, colour, and concentration of $\mathrm{Al}, \mathrm{Fe}, \mathrm{Cu}, \mathrm{Ni}, \mathrm{Sn}$, and $\mathrm{S}^{2-}$

\section{Experimental Design}

Optimizing heavy metal precipitation from industrial wastewater was carried out using the surface response method and Statistica 10 software. The following values were adopted for determining dependent and independent variables: $\mathbf{x}_{1}-\mathrm{pH}, \mathbf{x}_{2}-\mathrm{Na}_{2}$ EDTA concentration, $\mathrm{mg} / \mathrm{L}, \mathbf{x}_{3}-44.26 \%$ dose of $\mathrm{Na}_{2} \mathrm{CS}_{3}$, $\mathrm{mL} / \mathrm{L}$ wastewater and $\mathbf{Z}_{1}-\sum_{\text {of metals }}$, i.e.: sum of $\mathrm{Cu}^{2+}, \mathrm{Ni}^{2+}$ and $\mathrm{Sn}^{2+}$ concentrations in treated wastewater, in $\mathrm{mg} / \mathrm{L}$. Based on the analysis of the preliminary research carried out by the authors and literature review, it was assumed that one of the conditions for obtaining low concentrations of metals in treated wastewater was wastewater $\mathrm{pH} 9$, while a dose of $44.26 \% \mathrm{Na}_{2} \mathrm{CS}_{3}$ per $1 \mathrm{~L}$ of examined wastewater $\left(\mathbf{x}_{3}\right)$ should be $0.13-0.19 \mathrm{~mL}$, which is about $50 \%$ of the stoichiometric dose. On the basis of raw wastewater tests it was found that the concentration of complex compounds expressed as $\mathrm{Na}_{2}$ EDTA is $20.9 \mathrm{mg} / \mathrm{L}$. Therefore, while planning the experiment, the concentration of $\mathrm{Na}_{2} \mathrm{EDTA}\left(\mathbf{x}_{2}\right)$ in the range of $25-75 \mathrm{mg} / \mathrm{L}$ was adopted, while taking into account the possibility of increasing the concentration of complexing compounds in industrial wastewater, and the necessity of demonstrating the effectiveness or ineffectiveness of the proposed technology, also in the case of increased concentrations of substances hindering the precipitation of heavy metals. At $\mathrm{pH}$ $\left(\mathbf{x}_{1}\right)$, the values of 8.75-9.25 were adopted to precipitate the predominant amount of heavy metals contained in the wastewater in the form of hydroxides. Finally: $\mathbf{x}_{1} \in\langle 8.75 ; 9.25\rangle, \mathbf{x}_{2} \in\langle 40.0 ; 60.0\rangle$, and $\mathbf{x}_{3} \in\langle 0.13 ; 0.19\rangle$ were adopted. It was assumed that the given ranges would be normalized in the range $\langle-1,+1\rangle$, which means: $\mathbf{x}_{1(-1)}$ $=8.75, \mathbf{x}_{1(0)}=9.00, \mathbf{x}_{1(+1)}=9.25, \mathbf{x}_{2(-1)}=40.0, \mathbf{x}_{2(0)}=50.0$, $\mathbf{x}_{2(+1)}=60.0, \mathbf{x}_{3(-1)}=0.13, \mathbf{x}_{3(0)}=0.16$, and $\mathbf{x}_{1(+1)}=0.19$. The initially adopted ranges were extended, which 
Table 1. Physicochemical parameters of wastewater from PCB production.

\begin{tabular}{|c|c|c|}
\hline Parameter & Unit & Value \\
\hline $\mathrm{pH}$ & - & 1.80 \\
\hline Electrical conductivity at $20^{\circ} \mathrm{C}$ & $\mu \mathrm{S} / \mathrm{cm}$ & 6,570 \\
\hline Turbidity & $\mathrm{NTU}$ & 26 \\
\hline Colour & $\mathrm{mg} \mathrm{Pt} / \mathrm{L}$ & 20 \\
\hline Chemical oxygen demand (COD) & $\mathrm{mg} \mathrm{O}_{2} / \mathrm{L}$ & 150 \\
\hline Total organic carbon $(\mathrm{TOC})$ & $\mathrm{mg} / \mathrm{L}$ & 48 \\
\hline Chlorides & $\mathrm{mg} / \mathrm{L}$ & 460 \\
\hline Sulfates & $\mathrm{mg} / \mathrm{L}$ & 200 \\
\hline Copper & $\mathrm{mg} / \mathrm{L}$ & 70.80 \\
\hline Tin & $\mathrm{mg} / \mathrm{L}$ & 3.36 \\
\hline Nickel & $\mathrm{mg} / \mathrm{L}$ & 1.10 \\
\hline Complexing agents $\left(\right.$ as $\mathrm{Na}_{2}$ EDTA) & $\mathrm{mg} / \mathrm{L}$ & 20.9 \\
\hline & &
\end{tabular}

resulted from normalization in the range of $\langle-\alpha, \alpha>$ instead of the predefined normalization in the range $<-1,1>$, for which $\alpha=1$. After accepting $\alpha=1.6818$ from the experiment plan, the ranges of the given parameters assumed the following values: $\mathbf{x}_{1(-\alpha)}=8.58, \mathbf{x}_{1(0)}=9.00, \mathbf{x}_{1(+\alpha)}=9.42$, $\mathbf{x}_{2(-\alpha)}=33.2, \mathbf{x}_{2(0)}=50.0, \mathbf{x}_{2(+\alpha)}=66.8, \mathbf{x}_{3(-\alpha)}=0.11$, $\mathbf{x}_{3(0)}=0.16$, and $\mathbf{x}_{1(+\alpha)}=0.21$. The experiment was planned using the experimental planning module in the Statistica 10 programme. Central composite design was used for planning, and 16 experiments were performed for three independent factors, i.e.: $\mathrm{pH}$, Na EDTA concentration, and $\mathrm{Na}_{2} \mathrm{CS}_{3}$ dose as shown in Table 3 . According to the presented plan, 16 experiments were performed, including two experiments (15C and 16C) in design centre using raw wastewater of the composition shown in Table 1.

Concentrations of individual metals determined in the treated wastewater were used to calculate the sum of metals expressed in $\mathrm{mg} / \mathrm{L}$. In the case of $\mathrm{Sn}^{2+}$ concentration (values $<0.05 \mathrm{mg} / \mathrm{L}$ ), the value $0 \mathrm{mg} / \mathrm{L}$ was used to calculate total concentration.

\section{Results and Discussion}

Table 2 shows the test results of treated wastewater obtained as a result of using stoichiometric doses of $\mathrm{Na}_{2} \mathrm{~S}$, TMT 15, Furosep CW3, and $\mathrm{Na}_{2} \mathrm{CS}_{3}$ for precipitation. As a result of the tests carried out, treated wastewater was obtained which contained in each case small amounts of $\mathrm{Ni}^{2+}$ and $\mathrm{Sn}^{2+}$ ions in the range of $0.009-0.054 \mathrm{mg} / \mathrm{L}$ and $<0.005-0.031 \mathrm{mg} / \mathrm{L}$, respectively. Wastewater with the lowest content of $\mathrm{Cu}^{2+}$ ions, i.e., $0.09 \mathrm{mg} / \mathrm{L}$, was obtained in an experiment where the stoichiometric amount of $\mathrm{Na}_{2} \mathrm{CS}_{3}$ was used to precipitate. In the remaining experiments, final
Table 2. Physicochemical parameters of wastewater treated using stoichiometric doses of $\mathrm{Na}_{2} \mathrm{~S}$, Furosep CW3, TMT 15, and $\mathrm{Na}_{2} \mathrm{CS}_{3}$.

\begin{tabular}{|c|c|c|c|}
\hline Parameter & Unit & \multicolumn{2}{|l|}{ Value } \\
\hline \multicolumn{4}{|c|}{ Precipitation using stoichiometric doses of $\mathrm{Na}_{2} \mathrm{~S}$} \\
\hline $\mathrm{pH}$ & - & \multicolumn{2}{|c|}{7.51} \\
\hline $\mathrm{Cu}$ & $\mathrm{mg} / \mathrm{L}$ & \multicolumn{2}{|c|}{1.51} \\
\hline Sn & $\mathrm{mg} / \mathrm{L}$ & \multicolumn{2}{|c|}{$<0.005$} \\
\hline $\mathrm{Ni}$ & $\mathrm{mg} / \mathrm{L}$ & \multicolumn{2}{|c|}{0.012} \\
\hline $\mathrm{S}^{2-}$ & $\mathrm{mg} / \mathrm{L}$ & \multicolumn{2}{|c|}{$<0.1$} \\
\hline $\mathrm{V}_{\text {of sludge after } 30 \text { min. sediment. }}$ & $\mathrm{mL}$ & \multicolumn{2}{|c|}{120} \\
\hline \multicolumn{4}{|c|}{ Precipitation using stoichiometric doses of Furosep CW3 } \\
\hline $\mathrm{pH}$ & - & \multicolumn{2}{|c|}{7.52} \\
\hline $\mathrm{Cu}$ & $\mathrm{mg} / \mathrm{L}$ & \multicolumn{2}{|c|}{3.49} \\
\hline $\mathrm{Sn}$ & $\mathrm{mg} / \mathrm{L}$ & \multicolumn{2}{|c|}{$<0.005$} \\
\hline $\mathrm{Ni}$ & $\mathrm{mg} / \mathrm{L}$ & \multicolumn{2}{|c|}{0.054} \\
\hline $\mathrm{S}^{2-}$ & $\mathrm{mg} / \mathrm{L}$ & \multicolumn{2}{|c|}{$<0.1$} \\
\hline$V_{\text {of sludge after } 30 \text { min. sediment. }}$ & $\mathrm{mL}$ & \multicolumn{2}{|c|}{230} \\
\hline \multicolumn{4}{|c|}{ Precipitation using stoichiometric doses of TMT 15} \\
\hline \multicolumn{2}{|c|}{ Precipitation stage } & I stage & II stage \\
\hline $\mathrm{pH}$ & - & 8.95 & 9.03 \\
\hline $\mathrm{Cu}$ & $\mathrm{mg} / \mathrm{L}$ & 10.5 & 1.02 \\
\hline Sn & $\mathrm{mg} / \mathrm{L}$ & $<0.005$ & 0.031 \\
\hline $\mathrm{Ni}$ & $\mathrm{mg} / \mathrm{L}$ & 0.0099 & 0.011 \\
\hline $\mathrm{S}^{2-}$ & $\mathrm{mg} / \mathrm{L}$ & $<0.1$ & $<0.1$ \\
\hline$V_{\text {of sludge after } 30 \text { min. sediment. }}$ & $\mathrm{mL}$ & 35 & 10 \\
\hline \multicolumn{4}{|c|}{ Precipitation using stoichiometric doses of $\mathrm{Na}_{2} \mathrm{CS}_{3}$} \\
\hline $\mathrm{pH}$ & - & \multicolumn{2}{|c|}{9.21} \\
\hline $\mathrm{Cu}$ & $\mathrm{mg} / \mathrm{L}$ & \multicolumn{2}{|c|}{0.09} \\
\hline $\mathrm{Sn}$ & $\mathrm{mg} / \mathrm{L}$ & \multicolumn{2}{|c|}{$<0.005$} \\
\hline $\mathrm{Ni}$ & $\mathrm{mg} / \mathrm{L}$ & \multicolumn{2}{|c|}{0.009} \\
\hline $\mathrm{S}^{2-}$ & $\mathrm{mg} / \mathrm{L}$ & \multicolumn{2}{|c|}{$<0.1$} \\
\hline $\mathrm{V}_{\text {of sludge after } 30 \mathrm{~min} \text {. sediment. }}$ & $\mathrm{mL}$ & \multicolumn{2}{|c|}{95} \\
\hline
\end{tabular}

concentrations of the $\mathrm{Cu}^{2+}$ ions ranged from 1.02 to $3.49 \mathrm{mg} / \mathrm{L}$, which probably indicates the need to use some excess of these reagents to further reduce the concentration of $\mathrm{Cu}^{2+}$ ions. In the course of the study using $\mathrm{Na}_{2} \mathrm{~S}$, a delicate smell of $\mathrm{H}_{2} \mathrm{~S}$ was felt during the initial precipitation phase, which was not observed in the other cases. The use of TMT 15 for precipitation of metals from wastewater containing both $\mathrm{Cu}^{2+}$ and $\mathrm{Ni}^{2+}$ ions was associated with the need for two-stage treatment and a long sedimentation time for precipitated sediments. The precipitated sediment, similar to 
Table 3. Experimental conditions and results of central composite design.

\begin{tabular}{|c|c|c|c|c|c|c|c|}
\hline \multirow{3}{*}{$\begin{array}{l}\text { The number } \\
\text { of the } \\
\text { experiment }\end{array}$} & \multicolumn{3}{|c|}{ Variables } & \multirow{2}{*}{\multicolumn{4}{|c|}{ Response }} \\
\hline & \multirow{2}{*}{$\frac{\text { Factor } 1}{\mathrm{pH}}$} & \multirow{2}{*}{$\begin{array}{c}\text { Factor } 2 \\
\mathrm{Na}_{2} \text { EDTA, } \mathrm{mL} / \mathrm{L}\end{array}$} & \multirow{2}{*}{$\frac{\text { Factor } 3}{\mathrm{Na}_{2} \mathrm{CS}_{3} \mathrm{~mL} / \mathrm{L}}$} & & & & \\
\hline & & & & $\mathrm{Cu}, \mathrm{mg} / \mathrm{L}$ & $\mathrm{Ni}, \mathrm{mg} / \mathrm{L}$ & $\mathrm{Sn}, \mathrm{mg} / \mathrm{L}$ & $\sum_{\text {of metals, }} \mathrm{mg} / \mathrm{L}$ \\
\hline 1 & 8.75 & 40.0 & 0.13 & 0.765 & 0.025 & $<0.05$ & 0.49 \\
\hline 2 & 8.75 & 40.0 & 0.19 & 0.605 & 0.025 & $<0.05$ & 0.35 \\
\hline 3 & 8.75 & 60.0 & 0.13 & 1.022 & 0.028 & $<0.05$ & 0.78 \\
\hline 4 & 8.75 & 60.0 & 0.19 & 0.923 & 0.027 & $<0.05$ & 0.67 \\
\hline 5 & 9.25 & 40.0 & 0.13 & 0.368 & 0.012 & $<0.05$ & 0.31 \\
\hline 6 & 9.25 & 40.0 & 0.19 & 0.309 & 0.011 & $<0.05$ & 0.20 \\
\hline 7 & 9.25 & 60.0 & 0.13 & 0.457 & 0.013 & $<0.05$ & 0.45 \\
\hline 8 & 9.25 & 60.0 & 0.19 & 0.398 & 0.012 & $<0.05$ & 0.17 \\
\hline 9 & 8.58 & 50.0 & 0.16 & 1.038 & 0.052 & $<0.05$ & 1.17 \\
\hline 10 & 9.42 & 50.0 & 0.16 & 0.365 & 0.015 & $<0.05$ & 0.56 \\
\hline 11 & 9.00 & 33.2 & 0.16 & 0.272 & 0.028 & $<0.05$ & 0.31 \\
\hline 12 & 9.00 & 66.8 & 0.16 & 0.649 & 0.040 & $<0.05$ & 0.55 \\
\hline 13 & 9.00 & 50.0 & 0.11 & 0.465 & 0.040 & $<0.05$ & 0.40 \\
\hline 14 & 9.00 & 50.0 & 0.21 & 0.049 & 0.020 & $<0.05$ & 0.07 \\
\hline $15(\mathrm{C})$ & 9.00 & 50.0 & 0.16 & 0.165 & 0.025 & $<0.05$ & 0.19 \\
\hline $16(\mathrm{C})$ & 9.00 & 50.0 & 0.16 & 0.176 & 0.023 & $<0.05$ & 0.18 \\
\hline
\end{tabular}

using Furosep ${ }^{\circledR} \mathrm{CW} 3$, consisted of very small size flocs that were not observed while $\mathrm{Na}_{2} \mathrm{~S}$ and $\mathrm{Na}_{2} \mathrm{CS}_{3}$ were used.

The smallest, total amount of sediment $(45 \mathrm{~mL})$ was obtained using TMT 15 precipitation, while the use of
$\mathrm{Na}_{2} \mathrm{CS}_{3}$ was associated with the formation of a slightly larger amount of sediment $(95 \mathrm{~mL})$. Since the use of $\mathrm{Na}_{2} \mathrm{CS}_{3}$ for precipitation proved to be the most effective, the optimization of metal removal from the examined

Table 4. Analysis of the experiment with the central composite design using Statistica 10. The sheet of estimators effects ANOVA model coefficients for the standardized values of the input values, at the significance level of 0.05 before excluding non-significant interaction of effects (4A) and after excluding non-significant interaction of effects (4B).

\begin{tabular}{|c|c|c|c|c|c|c|c|c|c|}
\hline \multicolumn{10}{|c|}{$4 \mathrm{~A}$} \\
\hline \multirow[b]{2}{*}{ Parameter } & \multicolumn{9}{|c|}{$\begin{array}{c}\text { Evaluation of the effects, } \sum, \mathrm{mg} / \mathrm{L}, \mathrm{R}^{2}=0.9616, \mathrm{R}_{a d j j}^{2}=0.9040 \\
3 \text { parameters, } 1 \text { block, } 16 \text { experiments, } \mathrm{MS}=0.0075\end{array}$} \\
\hline & Effect & $\begin{array}{l}\text { Standard } \\
\text { error }\end{array}$ & p-value & $\begin{array}{c}-95 \%, \\
\text { confidence } \\
\text { intervals }\end{array}$ & $\begin{array}{c}+95 \% \\
\text { confidence } \\
\text { intervals }\end{array}$ & Factor & $\begin{array}{c}\text { Standard } \\
\text { error of } \\
\text { factor }\end{array}$ & $\begin{array}{c}-95 \%, \\
\text { confidence } \\
\text { intervals }\end{array}$ & $\begin{array}{c}+95 \%, \\
\text { confidence } \\
\text { intervals }\end{array}$ \\
\hline Constant Value & 0.195 & 0.061 & 0.0187 & 0.046 & 0.344 & 0.195 & 0.061 & 0.046 & 0.344 \\
\hline $\mathrm{pH},(\mathrm{L})$ & -0.320 & 0.047 & 0.0005 & -0.435 & -0.206 & -0.160 & 0.023 & -0.217 & -0.103 \\
\hline $\mathrm{pH}(\mathrm{Q})$ & 0.433 & 0.057 & 0.0003 & 0.294 & 0.572 & 0.217 & 0.028 & 0.147 & 0.286 \\
\hline $\mathrm{Na}_{2}$ EDTA, mg/L, (L) & 0.165 & 0.047 & 0.0126 & 0.050 & 0.279 & 0.082 & 0.023 & 0.025 & 0.140 \\
\hline $\mathrm{Na}_{2}$ EDTA, mg/L, (Q) & 0.126 & 0.057 & 0.0692 & -0.013 & 0.265 & 0.063 & 0.028 & -0.007 & 0.132 \\
\hline $\mathrm{Na}_{2} \mathrm{CS}_{3}, \mathrm{~mL} / \mathrm{L},(\mathrm{L})$ & -0.175 & 0.047 & 0.0096 & -0.290 & -0.060 & -0.088 & 0.023 & -0.145 & -0.030 \\
\hline $\mathrm{Na}_{2} \mathrm{CS}_{3}, \mathrm{~mL} / \mathrm{L},(\mathrm{Q})$ & -0.012 & 0.057 & 0.8363 & -0.151 & 0.127 & -0.006 & 0.028 & -0.076 & 0.063 \\
\hline $\mathrm{pH} / \mathrm{Na}_{2} \mathrm{EDTA},(\mathrm{L})$ & -0.125 & 0.061 & 0.0870 & -0.275 & 0.025 & -0.063 & 0.031 & -0.137 & 0.012 \\
\hline $\mathrm{pH} / \mathrm{Na}_{2} \mathrm{CS}_{3}(\mathrm{~L})$ & -0.035 & 0.061 & 0.5880 & -0.185 & 0.115 & -0.018 & 0.031 & -0.092 & 0.057 \\
\hline $\mathrm{Na}_{2} \mathrm{EDTA} / \mathrm{Na}_{2} \mathrm{CS}_{3},(\mathrm{~L})$ & -0.035 & 0.061 & 0.5880 & 0.185 & 0.115 & -0.017 & 0.031 & -0.092 & 0.057 \\
\hline
\end{tabular}


Table 4. Continued.

\begin{tabular}{|c|c|c|c|c|c|c|c|c|c|}
\hline \multicolumn{10}{|c|}{$4 \mathrm{~B}$} \\
\hline \multirow[b]{2}{*}{ Parameter } & \multicolumn{9}{|c|}{$\begin{array}{c}\text { Evaluation of the effects, } \sum, \mathrm{mg} / \mathrm{L}, \mathrm{R}^{2}=0.9307, \mathrm{R}_{\text {adj. }}^{2}=0.8845 \\
3 \text { parameters, } 1 \text { block, } 16 \text { experiments, MS }=0.0090\end{array}$} \\
\hline & Effect & $\begin{array}{l}\text { Standard } \\
\text { error }\end{array}$ & $\mathrm{p}$-value & $\begin{array}{l}-95 \%, \\
\text { confidence } \\
\text { intervals }\end{array}$ & $\begin{array}{c}+95 \% \\
\text { confidence } \\
\text { intervals }\end{array}$ & Factor & $\begin{array}{l}\text { Standard } \\
\text { error of } \\
\text { factor }\end{array}$ & $\begin{array}{c}-95 \%, \\
\text { confidence } \\
\text { intervals }\end{array}$ & $\begin{array}{c}+95 \%, \\
\text { confidence } \\
\text { intervals }\end{array}$ \\
\hline Constant Value & 0.195 & 0.067 & 0.0172 & 0.044 & 0.346 & 0.195 & 0.067 & 0.044 & 0.346 \\
\hline $\mathrm{pH},(\mathrm{L})$ & -0.320 & 0.051 & 0.0002 & -0.436 & -0.204 & -0.160 & 0.026 & -0.218 & -0.102 \\
\hline $\mathrm{pH}(\mathrm{Q})$ & 0.433 & 0.062 & 0.0001 & 0.292 & 0.574 & 0.217 & 0.031 & 0.146 & 0.287 \\
\hline $\mathrm{Na}_{2} \mathrm{EDTA}, \mathrm{mg} / \mathrm{L},(\mathrm{L})$ & 0.165 & 0.051 & 0.0108 & 0.048 & 0.281 & 0.082 & 0.026 & 0.024 & 0.140 \\
\hline $\mathrm{Na}_{2}$ EDTA, mg/L, (Q) & 0.126 & 0.062 & 0.0748 & -0.015 & 0.267 & 0.063 & 0.031 & -0.008 & 0.133 \\
\hline $\mathrm{Na}_{2} \mathrm{CS}_{3}, \mathrm{~mL} / \mathrm{L},(\mathrm{L})$ & -0.175 & 0.051 & 0.0078 & -0.291 & -0.059 & -0.088 & 0.026 & -0.146 & -0.029 \\
\hline $\mathrm{Na}_{2} \mathrm{CS}_{3}, \mathrm{~mL} / \mathrm{L},(\mathrm{Q})$ & -0.012 & 0.062 & 0.8484 & -0.153 & 0.129 & -0.006 & 0.031 & -0.077 & 0.064 \\
\hline
\end{tabular}

wastewater was carried out using this reagent. Table 3 shows the concentrations of copper, nickel, and tin in treated wastewater obtained in each of the 16 experiments conducted according to the generated design. The smallest value of the sum of metals was obtained in the $14^{\text {th }}$ experiment, and the largest in the third experiment (i.e., 0.07 and $0.78 \mathrm{mg} / \mathrm{L}$, respectively). Table $4 \mathrm{~A}$ shows a sheet of ANOVA estimator effects and model coefficients for normalized input values, which are the result of a preliminary statistical analysis of the experimental data. Although the conducted statistical analysis indicated five statistically significant parameters, all major linearquadratic effects were adopted for further analysis while the non-significant effects of linear-linear interactions (i.e., $\mathrm{pH} / \mathrm{EDTA}(\mathrm{L}), \mathrm{pH} / \mathrm{Na}_{2} \mathrm{CS}_{3}(\mathrm{~L})$ and $\mathrm{Na}_{2}$ EDTA/ $\mathrm{Na}_{2} \mathrm{CS}_{3}(\mathrm{~L})$ ), for which $\mathrm{p}>0.05$ were excluded from the model. The results of the re-conducted analysis, excluding non-significant interactions, are presented in Table 4B. As a result of the analysis, coefficients of approximation function shown in the 'effect' column were obtained and the verification of significance was carried out under the assumed significance level of $\alpha=0.05$. The conducted analysis confirmed the significance of five coefficients while the calculated coefficient of determination $\left(R^{2}\right)$ was 0.9307 , and the corrected coefficient of determination $\left(\mathrm{R}_{a d j}^{2}\right)$ was 0.8845 , which means that $88.45 \%$ of the dependent variable can be explained by a square model. The values of both coefficients indicated a good adjustment of the model to the experimental data, despite the exclusion of linear-linear interaction of effects. An increased $\mathrm{R}^{2}$ value can be achieved by adding statistically insignificant variables (Table 4A), thus a better indicator of model adjustment for experimental data is $\mathrm{R}_{a d j .}^{2}[18]$. It should also be noted that after excluding statistically insignificant linear-linear interactions from the model, the difference $\mathrm{R}^{2}-\mathrm{R}_{a d j}^{2}$ is smaller (0.0462) than for the model taking into account the presence of these variables (0.0576).

The analysis also yielded a small mean square error (MS), i.e., 0.009. Table 5 shows the adequacy verification

Table 5. Analysis of the experiment with the central composite design using Statistica 10. The verification of the adequacy of the model using ANOVA at the significance level of 0.05 after excluding the non-significant linear-linear interaction of effects.

\begin{tabular}{|c|c|c|c|c|}
\hline \multirow[t]{2}{*}{ Parameter } & \multicolumn{4}{|c|}{$\begin{array}{c}\text { Evaluation of the effects, } \sum, \mathrm{mg} / \mathrm{L} \\
\qquad \mathrm{R}^{2}=0.9307, \mathrm{R}_{a d j}^{2}=0.8845 \\
3 \text { parameters, } 1 \text { block, } 16 \text { experiments, } \mathrm{MS}=0.0090\end{array}$} \\
\hline & SS & MS & $\mathrm{F}$ & p-value \\
\hline $\mathrm{pH},(\mathrm{L})$ & 0.350 & 0.350 & 38.848 & 0.0002 \\
\hline $\mathrm{pH},(\mathrm{Q})$ & 0.435 & 0.435 & 48.262 & 0.0001 \\
\hline $\mathrm{Na}_{2}$ EDTA, mg/L, (L) & 0.092 & 0.092 & 10.265 & 0.0108 \\
\hline $\mathrm{Na}_{2}$ EDTA, mg/L, (Q) & 0.037 & 0.037 & 4.0580 & 0.0748 \\
\hline $\mathrm{Na}_{2} \mathrm{CS}_{3}, \mathrm{~mL} / \mathrm{L},(\mathrm{L})$ & 0.105 & 0.105 & 11.610 & 0.0078 \\
\hline $\mathrm{Na}_{2} \mathrm{CS}_{3}, \mathrm{~mL} / \mathrm{L},(\mathrm{Q})$ & 0.001 & 0.001 & 0.039 & 0.8484 \\
\hline
\end{tabular}

SS-predicted residual error sum of squares, MS-mean square, F-statistics 


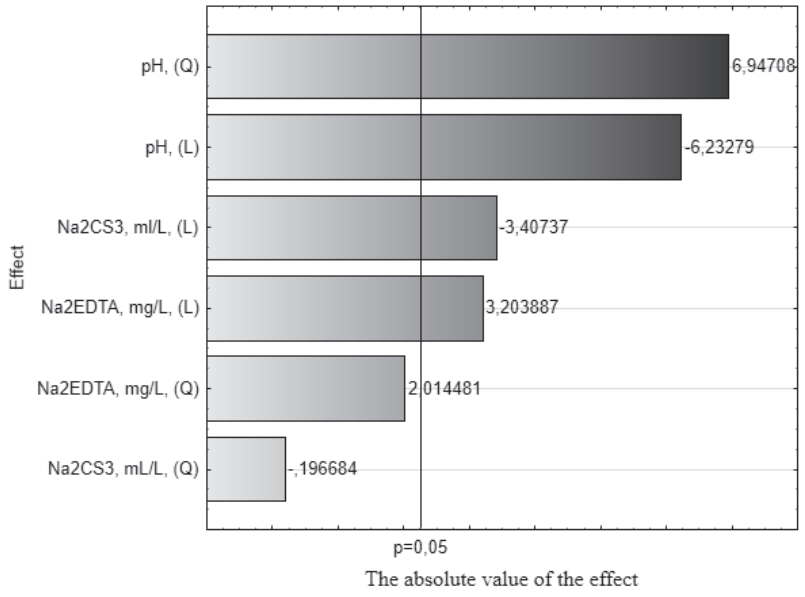

Fig. 2. Pareto chart showing the absolute value of standardized assessment of the effects $\left(\sum_{\text {of metals }}, \mathrm{mg} / \mathrm{L}, 3\right.$ values, 1 block, 16 experiments, $\mathrm{MS}=0.0090$ )

with the use of ANOVA. The adequacy verification performed using ANOVA indicated the importance of four main input parameters, i.e., $\mathrm{pH}(\mathrm{L}), \mathrm{pH}(\mathrm{Q})$, $\mathrm{Na}_{2} \operatorname{EDTA}(\mathrm{L})$, and $\mathrm{Na}_{2} \mathrm{CS}_{3}(\mathrm{~L})$. Fig. 2 shows a Pareto chart showing estimators of standardized effects that were ordered according to their absolute value, while the vertical line shows the minimum values of statistically significant effects at significance level $\alpha=0.05$. The data presented in Fig. 2 shows the significance of four main factors, i.e., $\mathrm{pH}(\mathrm{Q}), \mathrm{pH}(\mathrm{L}), \mathrm{Na}_{2} \mathrm{CS}_{3}(\mathrm{~L})$, and $\mathrm{Na}_{2} \mathrm{EDTA}(\mathrm{L})$, and non-significance (or minor significance) of the two main factors, i.e., $\mathrm{Na}_{2} \mathrm{EDTA}(\mathrm{Q})$ and $\mathrm{Na}_{2} \mathrm{CS}_{3}(\mathrm{Q})$. In order to visually verify the quality of the adjustment of the experimental data to the created model, a graph of the dependence of the estimated values versus the observed values was presented in Fig. 3 .

The presented relationship shows a good adjustment of the experimental values to the approximated values, which, combined with the values of the calculated

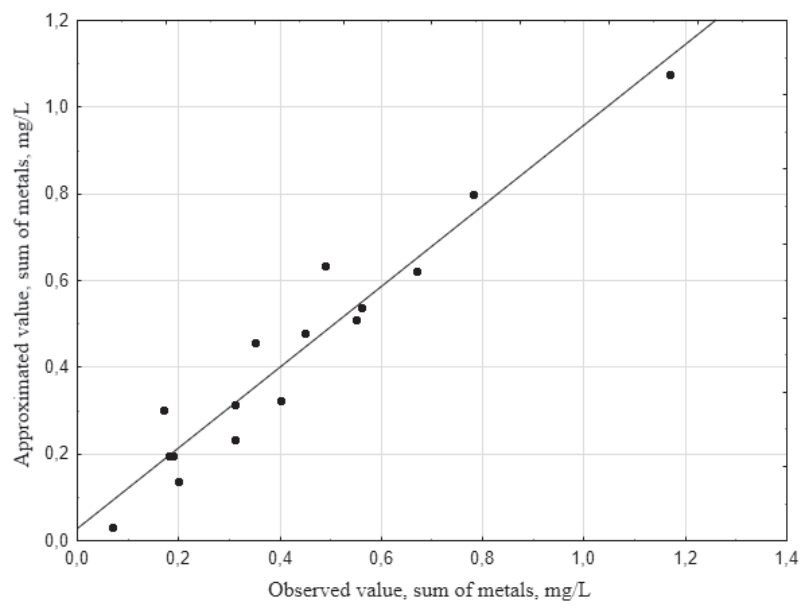

Fig. 3. Estimated vs. observed value plots $\left(\sum_{\text {of metals }}, \mathrm{mg} / \mathrm{L}, 3\right.$ values, 1 block, 16 experiments, MS $=0.0090$ ). determinants for the model, indicates that the created model is suitable for the obtained experimental data. Fig. 4a) presents a change in the sum of metals in relation to $\mathrm{Na}_{2}$ EDTA and $\mathrm{pH}$, assuming constant dose of $\mathrm{Na}_{2} \mathrm{CS}_{3} 0.13 \mathrm{~mL} / \mathrm{L}$. The conducted model studies indicated that at a fixed dose of $\mathrm{Na}_{2} \mathrm{CS}_{3}$ of $0.13 \mathrm{~mL} / \mathrm{L}$ and $\mathrm{Na}_{2}$ EDTA concentration of c.a. $34-53 \mathrm{mg} / \mathrm{L}$, the use of precipitation $\mathrm{pH}$ of about 8.9-9.2 resulted in the wastewater having the smallest value of total metal content. Model studies have shown that, as $\mathrm{Na}_{2}$ EDTA concentration increases, the total metal content is also increased, which means that they are difficult to remove with the adopted dose of $\mathrm{Na}_{2} \mathrm{CS}_{3}$. There is also a slight reversal trend that involves the increase in the sum of metals as $\mathrm{Na}_{2}$ EDTA concentration decreases. This seemingly abnormal relationship may be due to the application of the $\mathrm{Na}_{2}$ EDTA addition just before the start of the precipitation process to achieve the concentrations specified in the experimental plan (raw wastewater contained $20.9 \mathrm{mg} / \mathrm{L} \mathrm{Na} \mathrm{ND}_{2}$ EDA) and disturbance of the balance of complexing reaction in the examined wastewater (presence of $\mathrm{Cu}^{2+}$ ions, $\mathrm{Cu}(\mathrm{OH})_{2}$ sediment, $\mathrm{Fe}^{3+}$ ions, $\mathrm{Fe}(\mathrm{OH})_{3}$ sediment, and other ions and $\mathrm{pH}$ changes). This may also be due to the properties of the response surface method that optimizes the process, indicating the optimum reaction process. The mathematical description of the change in the sum of metals after eliminating the non-significant interaction as a function of $\mathrm{Na}_{2} \mathrm{EDTA}$ concentration and $\mathrm{pH}$, assuming the use of constant dose of $\mathrm{Na}_{2} \mathrm{CS}_{3}$ for precipitation (i.e., $0.13 \mathrm{~mL} / \mathrm{L}$, is presented by Equation (1):

$$
\begin{gathered}
\sum_{\text {of metals }}=287.838-63.023[\mathrm{pH}]+3.466[\mathrm{pH}]^{2} \\
-0.055\left[\mathrm{Na}_{2} \text { EDTA }\right]+0.001\left[\mathrm{Na}_{2} \text { EDTA }\right]^{2}
\end{gathered}
$$

Fig. 4b) depicts a change in the sum of metals depending on the dose of $\mathrm{Na}_{2} \mathrm{CS}_{3}$ and $\mathrm{pH}$, assuming a constant concentration of $\mathrm{Na}_{2}$ EDTA $50 \mathrm{mg} / \mathrm{L}$. The model study indicated that the smallest values of total metal content in treated wastewater were obtained in the $\mathrm{pH}$ range of 9-9.15 using c.a. $0.21 \mathrm{~mL} / \mathrm{L}$ of $\mathrm{Na}_{2} \mathrm{CS}_{3}$ solution for precipitation and a fixed dose of $\mathrm{Na}_{2}$ EDTA $50 \mathrm{mg} / \mathrm{L}$. The obtained results again pointed to the need to conduct the process at the optimum $\mathrm{pH}$ range, since as $\mathrm{pH}$ increases or decreases, the total metal content increases. In addition, as the dose of the precipitant increases, the total metal content is reduced, but it is the largest in the optimum $\mathrm{pH}$ range, where the efficiency of the precipitant is the greatest. The mathematical description of the change in total metal content, after elimination from the model of non-significant interaction as a function of $\mathrm{Na}_{2} \mathrm{CS}_{3}$ dose and $\mathrm{pH}$ (assuming constant $\mathrm{Na}_{2}$ EDTA concentration, i.e., $50 \mathrm{mg} / \mathrm{L}$ ), as presented by Equation (2):

$$
\begin{gathered}
\sum_{\text {of metals }}=286.971-63.023[\mathrm{pH}]+3.466[\mathrm{pH}]^{2} \\
-0.736\left[\mathrm{Na}_{2} \mathrm{CS}_{3}\right]-6.814\left[\mathrm{Na}_{2} \mathrm{CS}_{3}\right]^{2}
\end{gathered}
$$


Fig. 4c) depicts a change in total metal content depending on the dose of $\mathrm{Na}_{2} \mathrm{CS}_{3}$ and $\mathrm{Na}_{2}$ EDTA concentrations assuming a constant value of $\mathrm{pH}$ 9. The lowest total metal values were obtained with a $\mathrm{Na}_{2} \mathrm{CS}_{3}$ dose of $0.21 \mathrm{~mL} / \mathrm{L}$ and EDTA concentration within $36-50 \mathrm{mg} / \mathrm{L}$ and constant value of $\mathrm{pH}$ 9. Model studies have shown that as $\mathrm{Na}_{2} \mathrm{CS}_{3}$ dose increases, a decrease in

a)

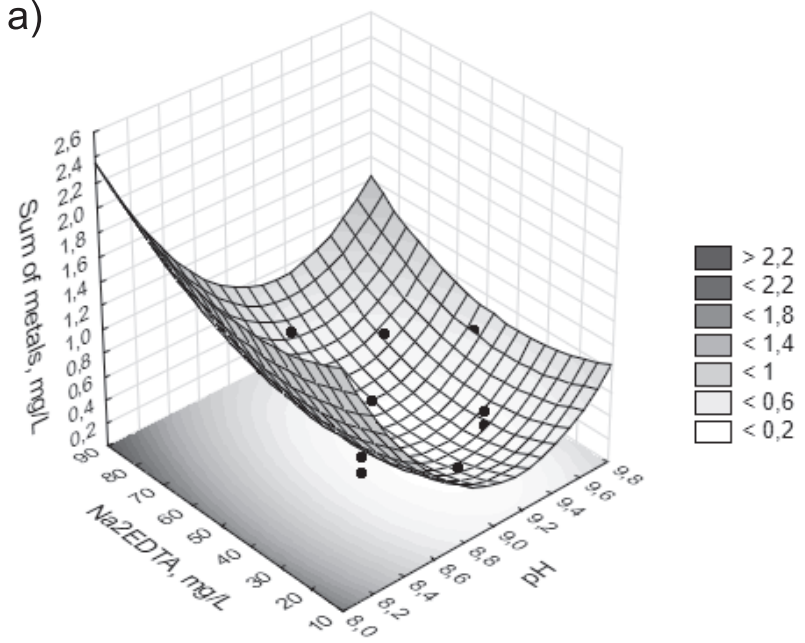

b)

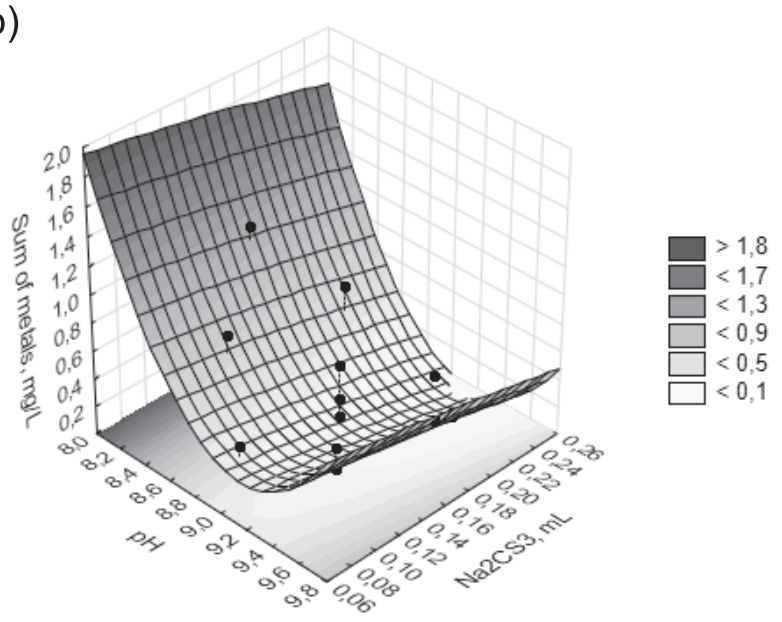

c)

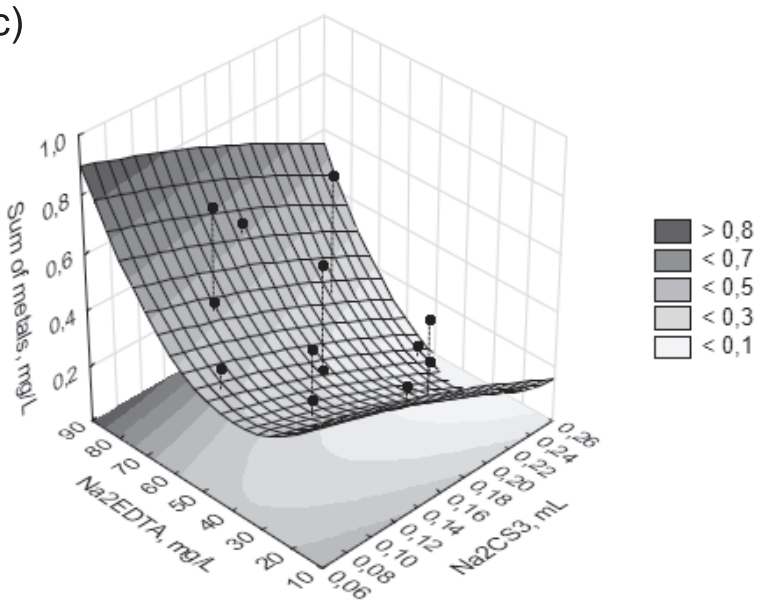

Fig. 4. Response surface plots for $\sum_{\text {of metals }}(\mathrm{mg} / \mathrm{L})$ with respect to $\mathrm{Na}_{2}$ EDTA and $\mathrm{pH}$ a), $\mathrm{Na}_{2} \mathrm{CS}_{3}$ and $\mathrm{pH}$ b), and $\mathrm{Na}_{2} \mathrm{CS}_{3}$ and $\mathrm{Na}_{2}$ EDTA c). total metal content is observed, and a similar correlation is observed when the concentration of the complexing compound decreases (i.e., $\mathrm{Na}_{2}$ EDTA). The reasons for a slight increase in total metal content due to the reduction in $\mathrm{Na}_{2}$ EDTA concentration shown in Fig. 4c) may be similar to those discussing the similar relationship shown in Fig. 4a). The mathematical description of the change in total metal content, after eliminating non-significant interactions as a function of $\mathrm{Na}_{2} \mathrm{CS}_{3}$ dose and $\mathrm{Na}_{2}$ EDTA concentration from the model (assuming a constant $\mathrm{pH}$ value of 9), is shown by Equation (3):

$$
\begin{gathered}
\sum_{\text {of metals }}=1.646-0.055\left[\mathrm{Na}_{2} \mathrm{EDTA}\right]+ \\
0.001\left[\mathrm{Na}_{2} \mathrm{EDTA}\right]^{2}-0.736\left[\mathrm{Na}_{2} \mathrm{CS}_{3}\right] \\
-6.814\left[\mathrm{Na}_{2} \mathrm{CS}_{3}\right]^{2}
\end{gathered}
$$

Table 6 shows the determination coefficients for the full model, taking into account all major linear-quadratic effects and linear-linear interaction effects (i.e., $\mathrm{pH} /$ EDTA(L), $\mathrm{pH} / \mathrm{Na}_{2} \mathrm{CS}_{3}(\mathrm{~L})$, and $\mathrm{Na}_{2}$ EDTA/ $\mathrm{Na}_{2} \mathrm{CS}_{3}(\mathrm{~L})$ ). To determine the approximation polynomial for the experimental data presented in Table 3, the general linear model (GLM) was adopted, using effects adjusted to the intergroup system, assuming that the grade II polynomial would be appropriate to describe precipitation of heavy metals from wastewater using $\mathrm{Na}_{2} \mathrm{CS}_{3}$ in the presence of $\mathrm{Na}_{2}$ EDTA. An approximation polynomial was obtained in the form of a 'forecast equation,' which describes the change in values of $\sum_{\text {of metals }}$ as a function of all independent factors, i.e., $\mathrm{pH}, \mathrm{Na}_{2}$ EDTA concentration, and $\mathrm{Na}_{2} \mathrm{CS}_{3}$ :

$$
\begin{gathered}
\sum_{\text {ofmetals }}=273.100-61.400[\mathrm{pH}]+3.466[\mathrm{pH}]^{2} \\
+0.180\left[\mathrm{Na}_{2} \mathrm{EDTA}\right]+0.001\left[\mathrm{Na}_{2} \mathrm{EDTA}\right]^{2} \\
+23.180\left[\mathrm{Na}_{2} \mathrm{CS}_{3}\right]-6.810\left[\mathrm{Na}_{2} \mathrm{CS}_{3}\right]^{2} \\
-0.025[\mathrm{pH}]\left[\mathrm{Na}_{2} \mathrm{EDTA}\right]-2.330[\mathrm{pH}] \\
{\left[\mathrm{Na}_{2} \mathrm{CS}_{3}\right]-0.058\left[\mathrm{Na}_{2} \mathrm{EDTA}\right]\left[\mathrm{Na}_{2} \mathrm{CS}_{3}\right]}
\end{gathered}
$$

The determinant for the full model $\left(\mathrm{R}^{2}=0.962\right)$ indicates a very good adjustment of the model to the experimental data, as well as the corrected coefficient of determination $\left(\mathrm{R}_{a d j .}^{2}=0.904\right)$. When all variables are included together with statistically non-significant ones, the difference $\mathrm{R}^{2}-\mathrm{R}_{a d j}^{2}$ is 0.058 and is it is slightly higher than for the model that does not take into account statistically non-significant linear-linear interactions (0.046). According to the authors, in the case of such small differences in determination coefficient values, a full model can also be applied to the mathematical description of the process of heavy metals removal from the examined wastewater. At the same time, the high value of the obtained adjusted coefficient of determination indicates a very good adjustment of the model approximating the equation to a set of other experimental data derived from precipitation processes of heavy metals from wastewater of a similar composition, derived from the processes of PCBs with $\mathrm{Na}_{2} \mathrm{CS}_{3}$ in the presence of $\mathrm{Na}_{2}$ EDTA and 
Table 6. Value of the determination coefficient (R) for the full model - a general linear model method.

\begin{tabular}{|c|c|c|c|c|c|c|c|c|}
\hline \multirow{2}{*}{ Parameter } & \multicolumn{8}{|c|}{ Test SS for the full model relative to the SS for the rest } \\
\cline { 2 - 10 } & $\mathrm{R}^{2}$ & $\mathrm{R}_{\text {adj. }}^{2}$ & $\begin{array}{c}\text { SS } \\
\text { Model }\end{array}$ & $\begin{array}{c}\text { MS } \\
\text { Model }\end{array}$ & $\begin{array}{c}\text { SS } \\
\text { Rest }\end{array}$ & $\begin{array}{c}\text { MS } \\
\text { Rest }\end{array}$ & F & p-value \\
\hline$\sum_{\text {of metals }}, \mathrm{mg} / \mathrm{L}$ & 0.962 & 0.904 & 1.124 & 0.125 & 0.045 & 0.007 & 16.692 & 0.001 \\
\hline
\end{tabular}

SS-predicted residual error sum of squares, MS-mean square, F-statistics

using the optimum $\mathrm{PH}$ range. Industrial tests were also carried out in a continuous treatment plant using $\mathrm{Na}_{2} \mathrm{CS}_{3}$ solution proportionally to the wastewater flow rate and heavy metals content, so as to obtain treated wastewater in which the maximum concentrations of the individual metals and sulphides would meet the requirements to which a wastewater treatment plant introducing treated wastewater to sewerage facilities is obliged $(\mathrm{Cu} 1 \mathrm{mg} / \mathrm{L}$, Ni $0.5 \mathrm{mg} / \mathrm{L}$, Sn $2 \mathrm{mg} / \mathrm{L}$, and $\left.\mathrm{S}^{2-} 1.0 \mathrm{mg} / \mathrm{L}\right)$. Table 7 shows the results of raw and treated wastewater with the use of $\mathrm{Na}_{2} \mathrm{CS}_{3}$ solution for precipitation. Due to the heterogeneous composition of wastewater - despite using storage tanks in a wastewater treatment plant which also fulfilled the function of averaging tanks - an increased dose of $\mathrm{Na}_{2} \mathrm{CS}_{3}$ solution was used, which enabled us to obtain treated wastewater containing very small amounts of metals and some excess precipitant causing an increase in $\mathrm{S}^{2-}$ ions in treated wastewater $(0.2-0.4 \mathrm{mg} / \mathrm{L})$. In none of these cases did values exceed the maximum possible sulphide concentrations in treated wastewater $(1 \mathrm{mg} / \mathrm{l})$. It is likely that in addition to the changes in metal concentrations in wastewater entering the treatment plant, there were also periodic changes in the concentration of complexing agents, which affected the effectiveness of the precipitant and was related to its temporary lower or higher demand. As a result of the adjustment of the dose of $\mathrm{Na}_{2} \mathrm{CS}_{3}$ solution, the wastewater was obtained in which the concentration of $\mathrm{Cu}^{2+}$ ions ranged between $<0.005-0.014 \mathrm{mg} / \mathrm{L}$ and for $\mathrm{Ni}^{2+}$ and $\mathrm{Sn}^{2+}$ ions amounting to $<0.01$ and $<0.005 \mathrm{mg} / \mathrm{L}$, respectively. In none of these cases was the permissible value specified in the waterlaw permit for the plant for each metal that has not been exceeded. As a result of the adopted method of metal precipitation, almost transparent and colourless wastewater with a low content of heavy metals was obtained, and the presented dosing method, consisting of adjusting the dose of $\mathrm{Na}_{2} \mathrm{CS}_{3}$ solution to the flow rate and metal content in wastewater, only requires the installation of the metering pump and the initial metal concentration control and a precipitant in treated wastewater at the dose adjustment phase, provided that an inflow of raw wastewater of uniform composition to the wastewater treatment plant is ensured.

\section{Conclusions}

Industrial wastewater from PCB production contains, in addition to heavy metal ions, complexing compounds that impede the quantitative removal of metals from wastewater. The laboratory scale tests allowed the choice of the precipitant $\left(\mathrm{Na}_{2} \mathrm{CS}_{3}\right)$ which, when used in the treatment of examined wastewater, guaranteed the effective removal of heavy metals. Optimization studies using the surface response method have allowed us to analyse the influence of particular parameters on the wastewater treatment efficiency expressed by the concentration of individual metals in the treated

Table 7. Physicochemical parameters of raw wastewater and wastewater treated using $\mathrm{Na}_{2} \mathrm{CS}_{3}\left({ }^{*} 1-\right.$ raw wastewater, $1 \mathrm{~A}-$ treated wastewater, etc.).

\begin{tabular}{|c|c|c|c|c|c|c|c|c|c|c|c|c|}
\hline \multirow{2}{*}{ Parameter } & \multicolumn{2}{|c|}{ Sample 1} & \multicolumn{2}{|c|}{ Sample 2} & \multicolumn{2}{|c|}{ Sample 3} & \multicolumn{2}{|c|}{ Sample 4} & \multicolumn{2}{|c|}{ Sample 5} & \multicolumn{2}{|c|}{ Sample 6} \\
\hline & $1 *$ & $1 \mathrm{~A}^{*}$ & 2 & $2 \mathrm{~A}$ & 3 & $3 \mathrm{~A}$ & 4 & $4 \mathrm{~A}$ & 5 & $5 \mathrm{~A}$ & 6 & $6 \mathrm{~A}$ \\
\hline $\mathrm{pH}$ & 2.5 & 8.0 & 5.9 & 9.1 & 6.4 & 9.5 & 6.3 & 9.5 & 6.9 & 9.4 & 6.0 & 9.6 \\
\hline Turbidity, NTU-IR & 8.6 & 7.5 & 17 & 7.6 & 27 & 4.4 & 31 & 5.4 & 12 & 2.9 & 7.8 & 5.4 \\
\hline Colour, mg Pt/L & 12 & 21 & 10 & 20 & 8 & 18 & 16 & 18 & 19 & 19 & 11 & 19 \\
\hline $\mathrm{Al}, \mathrm{mg} / \mathrm{L}$ & - & $<0.03$ & - & $<0.03$ & - & $<0.03$ & - & $<0.03$ & - & $<0.03$ & - & $<0.03$ \\
\hline $\mathrm{Fe}, \mathrm{mg} / \mathrm{L}$ & - & 0.3 & - & 0.5 & - & 0.5 & - & 0.4 & - & 0.3 & - & 0.2 \\
\hline $\mathrm{Cu}, \mathrm{mg} / \mathrm{L}$ & 26.9 & 0.008 & 19.1 & 0.011 & 18.1 & 0.012 & 14.6 & $<0.005$ & 7.10 & 0.014 & 85.0 & $<0.005$ \\
\hline $\mathrm{Sn}, \mathrm{mg} / \mathrm{L}$ & 2.69 & $<0.005$ & 1.13 & $<0.005$ & 5.05 & $<0.005$ & 2.51 & $<0.005$ & 0.71 & $<0.005$ & 4.3 & $<0.005$ \\
\hline $\mathrm{Ni}, \mathrm{mg} / \mathrm{L}$ & 0.031 & $<0.01$ & 0.068 & $<0.005$ & 0.034 & $<0.005$ & 0.045 & $<0.01$ & 0.041 & 0.008 & 0.76 & $<0.005$ \\
\hline $\mathrm{S}^{2-}, \mathrm{mg} / \mathrm{L}$ & $<0.1$ & 0.4 & $<0.1$ & 0.4 & $<0.1$ & 0.3 & $<0.1$ & 0.20 & $<0.1$ & 0.1 & $<0.1$ & 0.3 \\
\hline
\end{tabular}


wastewater. According to the authors, the use of methods for planning experiments to optimize wastewater treatment processes is very useful and fully justified, but the interpretation of the obtained results always requires critical analysis in the context of knowledge of the technological process and the chemical reactions taking place. The use of $\mathrm{Na}_{2} \mathrm{CS}_{3}$ on an industrial scale enabled the efficient precipitation of metals from wastewater and, consequently, the production of treated wastewater with parameters complying with the requirements of the relevant legal norms issued for wastewater treatment plants introducing wastewater to wastewater facilities.

\section{References}

1. SRIVASTAVA N.K., MAJUMDER C.B. Novel biofiltration methods for the treatment of heavy metals from industrial wastewater. Journal of Hazardous Materials, 151 (1), 1, 2008.

2. OCHOA-HERRERA V., LEON G., BANIHANI Q., FIELD J.A., SIERRA-ALVAREZ R. Toxicity of copper(II) ions to microorganisms in biological wastewater treatment systems. Science of The Total Environment Volumes 412-413, 380, 2011.

3. STANKOVIC V., BOZIC D., GORGIEVSKI M., BOGDANOVIC G. Heavy metal ions adsorption from mine waters by sawdust. Chemical Industry and Chemical Engineering Quarterly 15, 237, 2009.

4. SIERRA-ALVAREZ R., HOLLINGSWORTH J., ZHOU M.S. Removal of copper in an integrated sulfate reducing bioreactor - crystallization reactor system. Environmental Science Technology 41, 1426, 2007.

5. THOMAS, M., BIAŁECKA, B., ZDEBIK, D. Sources of copper ions and selected methods of their removal from wastewater from the printed circuits board production, Inżynieria Ekologiczna 37, 31, 2014.

6. SVECEVIČIUS G. Acute Toxicity of Nickel to Five Species of Freshwater Fish. Polish Journal of Environmental Studies 19, 2, 453, 2010.

7. BRIX K.V., SCHLEKAT CH.E., GARMAN E.R. The mechanisms of nickel toxicity in aquatic environments: An adverse outcome pathway analysis, Environmental Toxicology and Chemistry 36, 1128, 2017.

8. DERMENTZIS K., CHRISTOFORIDIS A., VALSAMIDOU E. Removal of nickel, copper, zinc and chromium from synthetic and industrial wastewater by electrocoagulation. International Journal of Environmental Sciences 5 (1), 697, 2011.

9. HOWE P., WATTS P., Tin and Inorganic Tin Compounds. Concise International Chemical Assessment. Document 65, World Health Organization, Geneva, 1-81, 2005. http:/ www.who.int/ipcs/publications/cicad/cicad_65_web_version.pdf. 20.04.2017.

10. GUNATILAKE S.K. Methods of Removing Heavy Metals from Industrial Wastewater, Journal of Multidisciplinary Engineering Science Studies 1(1), 12, 2015.

11. FU F., WANG Q. Removal of heavy metal ions from wastewaters: A review. Journal of Environmental Management 92, 407, 2011.

12. NAIM, R., KISAY L., PARK J., QAISAR M., ZULFIQAR, A.B., NOSHIN M., JAMIL K. Precipitation Chelation of Cyanide Complexes in Electroplating Industry Wastewater. International Journal of Environmental Research 4 (4), 735, 2010.

13. ABU-EL-HALAWA R., ZABIN S.A. Removal efficiency of $\mathrm{Pb}, \mathrm{Cd}, \mathrm{Cu}$ and $\mathrm{Zn}$ from polluted water using dithiocarbamate ligands. Journal of Taibah University for Science 11 (1), $57,2017$.

14. FU F., ZENG H., CAI Q., QIU R., YU J., XIONG Y. Effective removal of coordinated copper from wastewater using a new dithiocarbamate-type supramolecular heavy metal precipitant, Chemosphere 69 (11), 1783, 2007.

15. ANDREOTTOLA G., CADONNA M., FOLADORI P., GATTI G., LORENZI F., NARDELLI P. Heavy metal removal from winery wastewater in the case of restrictive discharge regulation. Water Science \& Technology 56 (2), 111, 2007.

16. PAN S.W., QIU K., SUN T.H., ZHANG H., JIA J.P. Application of chelating agents for heavy metal removal from electroplating effluent Xiandai Huagong/Modern Chemical Industry 35, 61, 2015.

17. YANG S., CHEN Y. Synergistic effects of chelating precipitation and flocculation on removal of cadmium aminocomplex from wastewater, Fresenius Environmental Bulletin 20 (12), 3235, 2011.

18. KUMAR J., BANSAL A. Photocatalytic degradation in annular reactor: Modelization and optimization using computational fluid dynamics (CFD) and response surface methodology (RSM). Journal of Environmental Chemical Engineering 1, 398, 2013. 
